\title{
The Urgency of Principle of Good Governance in Environmental Protection and Management: Case Study of Sepat Reservoir Surabaya
}

\author{
Nabbilah Amir \\ Faculty of Law, Universitas Surabaya, Indonesia \\ Email: nabila.amir@staff.ubaya.ac.id
}

\begin{abstract}
Transfer of Land Functions in Indonesia increasingly shows a graph of rapid increase even uncontrolled, mainly in the conversion of agricultural land into residential land. Increased settlement needs are based on an increase in the population of an area, as happened in the city of Surabaya, the conversion of functions becomes one of the steps to meet the primary needs of the community, namely settlements. In addition, the need for public facilities to meet the secondary needs of the community, however, land conversion is always the origin of environmental damage. Therefore this study aims to find out and analyze the consequences of the conversion of the sepat reservoir area involving the Surabaya City government with the company PT. CS became a luxury housing area and made the sepat reservoir as part of its yard, which had an impact on the closure of the sepat reservoir. This study uses empirical legal research methods and uses a case approach method. The results of this study indicate that there are legal implications of the lack of transparency in the public administration documents of the sepat reservoir, fearing that it would lead to a bad precedent for the administration of government in the city of Surabaya. Implementation of good governance principles by opening the sepat reservoir public administration document in order to provide a sense of security and foster the trust of the Surabaya City residents to the Government. The result of the study after the analysis was found there was an omission by the Surabaya city government on the sepat reservoir case, considering that there had been a civil agreement to exchange the sepat reservoir with the Gelora Bung Tomo (GBT) land which had been going on for a long time and if the government made unilateral blocking then it would civil disputes arose between Surabaya city government and PT.CS.
\end{abstract}

Keywords-Good Governance; Environmental; Spatial

\section{INTRODUCTION}

Regional infrastructure development is a reference for improving community facilities, especially for developing regions, implementation of development easily, smoothly so as to produce good facilities and quality for the community. However, in terms of increasing infrastructure development, it does not always run smoothly, various problems arise as the problems in Surabaya are one of them, the impact of the issuance of the Surabaya City Government Decree which implies contra of the decision. Efforts to increase infrastructure development were made by the Surabaya City Government with PT. CS, where the Surabaya City Government facilitates land clearing for the construction of the Surabaya Sport Center (SSC) or better known as the Gelora Bung Tomo (GBT). The initial plan began in 2007 as a land swap step between PT. CS, which owns 20.4 hectares of land in Pakal. Based on the plan, GBT will be built by the Surabaya City Government with compensation for the land exchange with the land owned by the Surabaya City Government in four villages namely 45 hectares Beringin Village, 6,7 hectares in Lidah Kulon Village, 6,7 hectares in Babat Jerawat Village and 4,3 hectares in Jeruk Village. In a short period of time, the Surabaya City Government got the approval of the Surabaya City DPRD through the issuance of Decree No. 39 of 2008 on 22 October 2007.
After receiving approval from the Surabaya City DPRD, the Surabaya City Government on 30 December 2008, issued Decree No. 188.45/366/436.1.2/2008 which confirms the approval of the DPRD, the Surabaya City Government conducts land swap with PT CS based on Joint Agreement Number 593/2423/436.3.2/2009 and Number 031/SY/sm/LAND-CPS/VI-09, dated 4 June 2009, handover was made on condition that PT. CS must make payments to the City Government of Surabaya for Rp. 14.9 billion. The land is officially owned by PT. CS is based on Building Use Rights Certificate (HGB) Number 4057/Kel. Lidah Kulon which was issued by Surabaya City Land Office on 23 December 2009. The problem that arises due to the land swap is that, among the land taken over by PT. CS there is a reservoir with an area of 6.675 hectares known as the sepat reservoir. Sepat Reservoir is a former Tanah Kas Desa (TKD) or bondhodeso which serves as a reservoir that is utilized by the Dukuh Sepat community, Lidah Kulon Village, Lakarsantri District, Surabaya City, utilization of ecosystems in reservoirs (fishing of small fish) and most importantly there is local wisdom which is very identical between the community and the sepat reservoir itself, one of which is the alms of the earth.

Various efforts have been made by the community to defend the sepat reservoir as their regional icon, ranging from lawsuits, police reports to the submission of information requests submitted by the Indonesian Forum for the 
Environment of East Java (WALHI East Java) on 4 May 2015 to the Mayor of Surabaya, after receiving no response. WALHI East Java sent an objection letter sent on 3 June 2015. Then disputed at the information commission, the East Java Province Information Commission's decision Number: 100/II/KI-Prof.Jatim-PS-AMA/2016 dated 24 February 2016, and sentenced the applicant object to paying court fees. Furthermore, at the decision of the Supreme Court (MA) No. $438 \mathrm{~K} / \mathrm{TUN} / 2016$ which clearly rejected the Surabaya Mayor's appeal to the public information suit, which had previously been won by WALHI East Java. Through this decision, WALHI East Java as the party that won the lawsuit, asked the Surabaya City Government to comply with the Supreme Court's decision. But until the ruling was set on 13 October 2016, the Surabaya City Government as the defendant did not open the related documents for swap (ruislag) and the function of Sepat Reservoir. In fact, dated 7 September 2017 the Surabaya City Government submitted a Judicial Review (PK) to the Supreme Court with Case number 111PK/TUN/2017 to WALHI East Java. WALHI East Java, LPBP and LBH Surabaya since 8 March 2017, tried to remind the Surabaya City Government through a letter addressed to Surabaya City Hall. The contents of the letter essentially appealed to the Surabaya City Government to open the requested public documents in accordance with the Supreme Court ruling. Decision of the Supreme Court that rejected the Judicial Review with case number 111PK/TUN/ 2017. So WALHI East Java together with LPBP and LBH Surabaya, demanded that the Mayor of Surabaya open a document. On 25 January 2018 residents took action at the city hall and got information if the Surabaya City Government did not have the requested documents and there was still no certainty to date.

This sepat reservoir swapping problem reaped many responses as outlined in studies. The previous research was carried out by [11] who conducted research related to the identi-fication of conflicts that occurred due to differences in views from the developer of PT.CS and local residents on the status of the reservoir land. The developer sees de jure land tenure through legal ownership issued by the government, namely the HGB (Hak Guna Bangunan) certificate that they have, while the surrounding community views de facto land tenure, based on its historical value that the reservoir is made up of citizens in the past. While the cause of this conflict itself is divided into three major spheres, namely environmental problems, ideology and historical values, and social welfare [11]. Furthermore, the research was also conducted by [16] on the Surabaya City Government's Policy on Land Mastery by Developers in the West Surabaya Area (Study of the Sepat Reservoir Lidah Kulon Case Dispute) which revealed the pattern of developer as developer, PT. CS on the land of the Surabaya City Government, namely the Sepah Kulon Sepat Reservoir, with the subject of PT. CS as the biggest developer in Surabaya. The author also analyzes the policy direction of the Surabaya City Government in relation to the dispute over the Sepat Reservoir Lidah Kulon using conflict theory that uses several concepts, including: power and policy. (Rury Widyani: 2012).

Based on the background description above, the formulation of the problem is drawn: How is the application of good governance principles in the Protection and Management of the Environment Especially in the Lidah Kulon Dam Surabaya?

\section{RESEARCH METHOD}

This study uses empirical legal research methods and uses a case approach method. Through the interview method to Wahyu Eka [25] as the mananger of education and networking at the Indonesian Forum for the Environment (WALHI) in East Java about the history of the sepat reservoir disputes, the legal efforts made by WALHI and the community as well as people's expectations of the settlement of the sepat reservoir dispute involving the community, the Surabaya city government and PT.CS. Furthermore, the study was also carried out directly to the field to determine the condition of the sepat reservoir as a primary research material. Using law books and journals relating to the case as secondary material from this study. Furthermore, in this study, an analysis based on the facts in the field, the results of the interviews and the legislation that is the basis for breaking down the problems to get a solution to the disputes that have occurred in recent years.

\section{RESULT AND DISCUSSION}

\section{A. Expert Impact on the Function of the Sepat Reservoir Land on the Environment Based on the UUPPLH}

Implementation of spatial planning in Indonesia is based on the existence of Law No. 26 of 2007 (hereinafter referred to as Law No. 26 of 2007) concerning spatial planning, which became the basis for the implementation of spatial planning, with the aim of providing monitoring of spatial plans, supervision of spatial planning, spatial control control, and spatial planning.

Spatial planning is a process of spatial planning, spatial utilization, and control of spatial utilization. Spatial planning is an activity that includes regulation, guidance, implementation and supervision of spatial planning. Whereas the arrangement of spatial planning is an effort to establish a legal basis for the government, regional government and the community in spatial planning [6].

Space utilization as stipulated in Law No. 26 of 2007 provides the essence of spatial planning as a necessity in spatial planning, so that space can be beneficial for citizens. Various activities in carrying out the spatial planning process, one of which is the expert on land functions. The transfer of function is a practice of changing land functions, from the function that already existed to a new function planned by certain parties concerned with the transfer of land functions. The implementation of this land function expert is often economical and fulfills the needs of the community. For example, experts in the function of agricultural land become residential land.

In every development in the spatial plan must contain the principle of justice. The principle of justice implies that in determining the policy of change, designation, function and use of agricultural land must pay attention to aspects of justice for 
the parties involved in it such as industry, housing and the food sector, both justice for future generations, and also including justice economically, socially and environmentally. [20].

The implementation of land conversion often gets rejection from the community especially if the land to be converted is land that has strategic potential in the area. For example, over the function of the land in the sepat reservoir lidah kulon village, lakarsantri, West Surabaya. Sepat Reservoir is an object of land swap dispute over regional assets of the Surabaya City Government with PT. CS, the community together with WALHI East Java rejects land ownership by PT. The CS. Where PT CS after the issuance of the HGB certificate on the land and the sepat reservoir is very high and is very closed, so that people who want to do activities in the sepat reservoir are not allowed. Land HGB certificate owned by PT. CS sepat reservoirs switch function to former soil rewards or yard land is no longer in accordance with the initial function of the sepat reservoir. In fact, before the apprenticeship was carried out by PT. CS, various community activities are carried out in the sepat reservoir both in terms of the people's activities related to the economy and those related to local wisdom. Communities around the sepat reservoir often do activities related to local wisdom, one of which is earth alms carried out routinely in the sepat reservoir and even the community hopes that the sepat reservoir can become an object of natural tourism and local wisdom so that it is not eroded by civilization.

The thing that was felt when the reservoir was closed was that the surrounding reservoir seemed lonely because it was able to unite social and community members who visited this reservoir only for fishing and hanging out. Besides that the loss of children's playground. It was known that the reservoir had once been a waste disposal from the housing area of the Citraland [15].

In connection with this, Wahyu Eka conveyed the following:

"Sepat reservoirs have been around since ancient times, water
reservoirs for rice fields have become a pattern of community
culture, typologically and geomorphologically there are three
reservoirs in the adjacent areas, namely sepat reservoirs, citrus
reservoirs and made reservoirs. However, orange reservoirs and
made reservoirs were first piled flat on the ground and became
housing areas controlled by three large developers" [25]

However, after the fencing, the community does not have the same access and freedom as before. Worse yet, the public can only peek through the small gaps in the fence. The impact of the conversion of the land in the sepat reservoir to the yard is quite worrying for the surrounding community because it is probable that the land is managed by PT. CS as a luxury housing developer to expand its business by closing the sepat reservoir in full like an orange reservoir which is also not far from the sepat reservoir area. In the case of spatial utilization carried out by the Surabaya City Government in conducting land swap, it should refer to the Regional Regulation of Surabaya City Spatial Plan 2014 2034 as a guideline so that in the city arrangement the government already has a spatial structure. "Space needs to be organized because of the limited natural resources, while human needs are more and more diverse." [10].

According to [9], the regional spatial plan (RTRW) of a region can be seen from a spatial, ecological, development, environmental management, juridical angle, in the context of land use and as a concept. The layout is always related to the land, place, region and time. It is a means of optimally utilizing resources as a direction of wisdom. Therefore spatial planning has a hierarchy and is dynamic in addition to being functional and/or formal [9].

In designing the Spatial Plan, the central and regional governments are required to pay attention to the principal principles and principles as stipulated in Article 2 of Law No. 26 of 2007 namely:

a. Principle of Integration;

b. Harmony Principle;

c. Sustainability Principle;

d. Principle of Power;

e. Openness Principle;

f. Togetherness and Partnership Principles;

g. Principles of Public Interest Protection;

h. Principle of Legal and Justice Certainty; and;

i. Accountability Principle.

These principles or principles of law are the basic foundation in spatial planning. Thus, if the determination of a spatial plan (land, sea and air, even the basement) in areas that are not in accordance with or contrary to the principles of law contained in Law No. 26 of 2007, the resulting spatial plan is null and void or can be canceled [2].

At present the land administration process for agricultural land refers to the designation directives in the regional spatial plan, by providing requirements for the use and use of land in accordance with land stewardship. Land must be able to be efficiently used in each of its utilization activities by taking into account the spatial plan of the relevant area [19].

The designation directives outlined based on the principles and principles of the RTRW should also be the basis for the Surabaya City Government in implementing space utilization. The context that occurs in the conversion of the sepat reservoir area is the Surabaya City Government, in fact it has not been optimal in applying the basic principles of spatial planning. The same thing also happened in the case of the closure of the citrus reservoir which was originally a reservoir (irrigation) for the surrounding agriculture is now closed and turned into a settlement. This is also the basis of community rejection along with WALHI East Java based on the function of the sepat reservoir as a function of water catchment areas during the rainy season, because the sepat reservoir in the West Surabaya area is an area prone to ecological disasters such as floods. Thus the presence of Sepat Reservoir and other reservoirs in the West Surabaya area functions, among others, first to stabilize the groundwater surface, so that in the dry season the surrounding residents can still use existing wells as a source of clean water. Both function as surface water runoff during the rainy season can be accommodated in the available reservoirs, thus reducing the volume of runoff that flows into the lower channel, considering the capacity of the downstream channel is very limited. 
Changes in the function of sepat reservoirs should be through Strategic Environmental Studies (KLHS). KLHS is one of the compulsory instruments in controlling and strengthening the environment in a sustainable manner for both central and regional governments as set forth in Law Number 32 of 2009 concerning Environmental Protection and Management (hereinafter referred to as the PPLH Law) the instrument ensures that sustainable development is the basis and integrated in the development of a region and / or policies, plans and / or programs to be the basis for prevention of environmental damage.

At present the environmental problem becomes a crucial problem which essentially affects sustainable urban development. When environmental imbalances occur, it can influence the policy implementation process. (Elvie Dyah Fitriana et al.: 218)

Environmental management is a business of resource utilization, but a distinctive feature is an integrated effort to preserve the function of the living environment which includes policies for structuring, utilizing, developing, maintaining, eliminating, controlling, and controlling the environment. (Hartuti Purnaweni: 55: 2014)

In safeguarding the environment in the midst of the magnitude of development, UUPPLH 2009 is present to provide instruments that are the basis of the government in carrying out environmental management, which consists of: Strategic Environmental Assessment (KLHS); Spatial; environmental quality standards; standard criteria for environmental damage; analysis of environmental impact (AMDAL); Environmental Management Efforts and Environmental Monitoring efforts (UKL-UPL); Licensing; Environmental economic instru-ments; environmental legislation; and other instruments according to the needs and / or development of science [3].

KLHS is a form of study that must be included in the establishment of a national spatial plan as well as the spatial plan for the implementation of the KLHS provisions set out in the UUPPLH which contains the direction/guidance in its application. KLHS is also considered to have similarities with Environmental Impact Analysis (AMDAL). The basis of which is the basis of AMDAL is an environmental feasibility study related to licensing which is the basis for decision making (Decision Making), while SEA is a study that is the formulation of decisions (Decision Aiding ) for the government.

KLHS is an instrument that is applied at the upstream level. Conducting KLHS at the upstream level, the potential to produce policies, plans and programs (hereinafter abbreviated as KRP) that are not in line with the principles of sustainable development can be anticipated early. The UUPPLH emphasizes that KLHS must be the basis for the preparation or evaluation of the RTRW, RPJP/RPJM and sector development policies, plans and programs that have the potential to cause environmental impacts or risks [14].

Observing this matter, it has become the obligation of the Regional Government of the City of Surabaya to pay attention to the principles and principles in designing the RTRW of the city of Surabaya based on KLHS before conducting the swap of the sepat reservoir land with the land that currently stands GBT in the area.
Meanwhile, in drafting environmental policies in terms of legal guidance and apparatus, it is necessary to consult and coordinate between all elements of the government and between elements of the government and the private sector with an interest in legal development and apparatus in environmental management, even furthermore, reference [7] emphasized that so that the Surabaya city government can anticipate all forms of land conversion that cause environmental damage.

\section{B. Application of the Good Governance Principle in the transfer of the sepat reservoir function}

After the issuance of the Supreme Court's Decree which rejected Judicial Review number 111PK/TUN/2017 with the basis of the lawsuit for the opening of public documents, the residents, WALHI East Java together with LPBP and LBH Surabaya, demanded that the Mayor of Surabaya open an administrative document for sepat reservoir land swap with GBT January 2018. Residents take action in the town hall and get information if the Surabaya City Government does not have or does not or does not keep the requested documents and after the action there is still no certainty about it.

Furthermore, at the time of the action the Surabaya City Government told residents, along with WALHI East Java, LPBP and LBH should ask the relevant agencies to open the documents for sepat reservoir land swap with GBT. The statement describes the situation as if the government is not ready to open the swap document. In fact, people were told to look for the document themselves. Therefore, the Surabaya City Government is considered to have been negligent in applying the general principles of good governance.

In this regard, Wahyu Eka presented the following:

"Citizens' demands after winning the simple MA actually open public information documents except information that is considered confidential. We need documents that are not confidential because they are only Environmental Permits, Strategic Environ-mental Studies, Housing Development Business Permits that are not opened because until now the government is considered to have no such documents " [25]

Looking at the complexity of the problem and its implications for developing good governance practices, giving priority to improving the performance of government bureaucracy in public services is a very strategic first step. Reference [17] stated that reforming the bureaucracy in the Surabaya City Government should begin not only from administrative staff but also officials who in this case arrived at the Surabaya mayor, considering that those responsible for a state administration decision in an area are Mayor.

In various laws that control administrative justice in the Netherlands, the general principles of good governance (ABBB) are referred to as the basis of appeal and testing (including Article 8 paragraph 1 below the AROB Wet). Gradually it has been accepted that the ABBB must be seen as unwritten legal norms, which must always be obeyed by the government, although the exact meaning of $\mathrm{ABBB}$ for each individual situation cannot always be accurately explained. It can also be said, that the ABBB, is, the principles of unwritten law, from which for certain 
circumstances legal rules can be applied that can be applied[5].

Good Governance is called in several terms, including:

1. Organizing a trustworthy government;

2. Good governance;

3. Good and responsible government mana-gement;

4. Good governance;

5. Clean government. [8]

In general, the administration of government referred to as Good Governance is related to the issues of transparency, public accountability and so on. In order to understand and make it happen, understanding of good governance is actually quite complicated and complex, not only regarding transparency and accountability. Conceptually it can also be understood that good governance shows a process that positions the people to manage their economy. Institutions and social and political sources are not only used for development, but also to create integration for the welfare of the people [8].

According to the United Nation Economic Commission of Europe, the principles of good governance include:

1. Participation: The involvement of all stakeholders;

2. Decency: The establishment and implementation of regulations is carried out without harm or causing complaints by the community;

3. Transparency: clarity and openness in decision making;

4. Accountability: the expansion of political actors who must be accountable to the community for what they say and do;

5. Fairness: rules must be treated equally for everyone in the community;

6. Efficiency: the implementation of available human and financial resources is not extravagant, procrastinating or corruption, or detrimental to future generations. (United National Economic Communication for Europe, Guidebook on Promoting Good Governance in Public-Private Partnership, (New York and Ganeva: United Nation, 2008 pp. 13-14)

The strategic plan in good governance, namely the need for a new approach to state administration and development that is directed at the realization of good governance, namely: "... The process of managing a democratic, professional government, upholding supermarkets and human rights, decentralized, parti-cipatory, transparent, fair, clean and accoun-table; besides being efficient, effective, and oriented towards increasing the competitiveness of the nation." [1].

The closure of the sepat reservoir swap document, kulon tongue with GBT Pakal between the Surabaya City Government and PT. CS creates a stigma that the Surabaya City government does not apply the principles of good governance in carrying out government activities which do not accommodate the principles of good governance. A description of the explanation of the principles of good governance associated with the conversion of the sepat reservoir function is explained as follows:

\section{Participation}

In the implementation of the exchange of sepat tong kulon reservoir with GBT Pakal does not involve all stakeholders, where the government does not carry out public tests to residents around the sepat reservoir. The public test is one of the basics of the Surabaya City Government to be able to carry out the sepat reservoir land swap or not be able to do the swap. Public testing is a question-and-answer process or discussion with the community related to the State Administration Decree (KTUN) relating to the community.

\section{Decency}

Whereas the KTUN issued by the Surabaya City Government led to the rejection of the community around the sepat reservoir because the KTUN could be detrimental to the surrounding community in addition to the local wisdom and the environment.

\section{Transparency}

The Surabaya City Government, since starting the sepat reservoir swap agreement with PT. CS in 2008 was considered not transparent to the people of Surabaya, until the issuance of the Supreme Court decision which won citizens and WALHI East Java to be able to open the sepat reservoir swap document with GBT the Surabaya City Government did not provide documents requested by the Citizens and WALHI East Java. The documents requested by the residents and WALHI East Java are Community Test, Strategic Environmental Study and several other documents that become the basis for permitting the conversion of the sepat reservoir area.

\section{Accountability}

Accountability in this case is also a question of the community, also WALHI East Java, where in the dispute process in the past few years the Surabaya City Government, led by the Mayor of Surabaya, never met directly with the people who opposed the KTUN. In the course of the dispute the Mayor of Surabaya as the leader of Surabaya City who was chosen for the political rights of the people of Surabaya City was always represented by his staff both from the Surabaya City Legal Bureau and other agencies.

\section{Fairness}

The application of the same attitude in the case of the sepat reservoir is that the regional government is demanded not to be selective in serving its community with any profession whatsoever. However, the fact is that the government just allowed the fencing of sepat reservoirs without regard to the contra in the community.

\section{Efficiency}

The Surabaya City Government in conducting the sepat reservoir swap with GBT can harm the future generation of Surabaya City. This is the result of the next generation which is increasingly distant from the local wisdom of the City of Surabaya no longer maintaining and strengthening local wisdom but tends to be individualist amidst the current of modernization. In addition, the impact of environmental damage will also be increasingly felt in future generations such as floods, increasing geothermal energy etc.

The principle of good governance is the main breath as an activator of organs in carrying out government activities. Moreover, in Act No. 14 of 2008 concerning public information disclosure, encourages the Surabaya City Government to implement good governance in a good and 
earnest manner so as to create harmony in the use of space, society and the wheels of government.

\section{CONCLUSION}

Based on the description above, it can be concluded that in the process of swap (ruislag) the sepat reservoir land with Bung Tomo (GBT) Pakal land there are some things that are not in accordance with the provisions in the UUPPLH where there is an obligation for the local government in evaluating the impact of the planned change of function the land is through the Strategic Environmental Assessment (KLHS) before the swap agreement is made, considering that if the agreement has been made then the land that becomes the object of exchange will be free to use by PT. CS.

However, if the Surabaya city government has previously entered into a land swap agreement then the other authority that can be exercised is in issuing land use permits through a series of inspection mechanisms and references to the Regional Spatial Plan (RTRW) so that if land use is not in accordance with environmental conditions and wisdom locally, the government has the right not to give permission to use the land.

The basic problem that is owned by the Surabaya city government is the Regional Regulation (Perda) regarding the Regional Spatial Plan which has not yet been completed. Whereas for an area as big as the city of Surabaya the RTRW Regional Regulation is very important in its existence in the arrangement of the city by taking into account the land, environmental and social conditions of the community.

Furthermore, in running the government synchronization between institutions in a government between one agency and another institution becomes the main focus in improving service given the application of the principle of good governance is the main foundation of governance. This is because the request for the document about the sepat reservoir by the community to throw each other's responsibilities between the Surabaya city government agencies which causes confusion to the sepat reservoir community to get the sepat reservoir documents they need. It is expected that the Surabaya city government can wisely resolve the case of the sepat reservoir, not only in a family but also gentle way to deal with the demands of the community considering the interests of the community are the main thing.

\section{REFERENCES}

[1] Anggara, Sahya., 2016, Ilmu Administrasi Negara (Kajian Konsep, Teori, dan fakta dalam Upaya Menciptakan Good Governence), Pustaka Setia, Bandung.

[2] Arba, 2017, Hukum Tata Ruang dan Tata Guna Tanah, Sinar Grafika, Jakarta Timur.

[3] Diantoro, Totok Dwi., 2016, UUPPLH 2009 Apresiasi dan Catatan Kritis, Gadjah Mada University Press,Yogyakarta.

[4] Efendi, A'an dan Freddy Poernomo, 2017, Hukum Administrasi, Sinar Grafika, Jakarta Timur.

[5] Hadjon, Philipus M. dkk, 2015, Pengantar Hukum Administrasi Indonesia, Gadjah Mada University Press, Yogyakarta.
[6] Hammar, Robert Kurniawan Ruslak, 2017, Penataan Ruang Berbasis Kearifan Lokal, Calpulis, Yogyakarta.

[7] Rangkuti, Siti Sundari., 2015, Hukum Lingkungan dan Kebijakan Lingkungan Nasional, Airlangga University Press, Surabaya.

[8] Ridwan, Juniarto dan Sodik Suderajat, 2017 Hukum Administrasi Negara (Dan Kebijakan layanan Publik), Nuansa Cendika, Bandung.

[9] Wahid, Yunus., 2016, Pengantar Hukum Tata Ruang, Kencana.

[10] Waskito dan Hadi Arnowo., 2017, Pertanahan, Agraria dan Tata Ruang, Kencana, Jakarta.

[11] Adhi Murti Citra Amalia H, Konflik Waduk Sepat, Jurnal AntroUnairDotNet, Vol.1/.No.1/Juli-Desember, 2012. Halaman 8-10

[12] Elvi Dyah Fitriana, Implementasi Kebijakan Tata Ruang Wilayah Dalam Mewujudkan Pembangunan Kota Berkelanjutan (Studi di Kabupaten Magetan) Jurnal Administrasi Publik (JAP), n.d, Vol.2, No 2, Hal. 217-223.

[13] Hartati Purnaweni, Kebijakan Pengelolaan Lingkungan Di Kawasan Kendeng Utara Propinsi Jawa Tengah, Jurnal Ilmu Lingkungan, 2Vol. 12 Issue 1 2014, Halaman 53-65.

[14] I Gusti Ayu Jatiana Manik Wedanti, Kajian Lingkungan Hidup Strategis Sebagai Bentuk Integrasi Prinsip Pembangunan Berkelanjutan Dalam Perencanaan Tata Ruang Wilayah,Jurnal Magister Hukum Udayana, Vol.5, No.3, September 2016. Halaman 528.

[15] Nuke Faridha Wardhani, Gerakan Lembaga Swadaya Masyarakat dalam Memperjuangkan Sengketa Lahan Waduk Sakti Sepat diKelurahan Lidah Kulon Surabaya, Jurnal Politik Muda Unair, Vol. 5, No. 2, April - Juli 2016, halaman 141

[16] Ruri Widyani, Kebijakan Pemerintah Kota Surabaya tentang Penguasaan Lahan oleh Pengembang di Wilayah Surabaya Barat Studi Tentang Sengketa Kasus Waduk Sepat Lidah Kulon, Jurnal Politik Muda Unair, Vol. 1, No. 1, OktoberDesember, 2012. Halaman 4-16.

[17] Sondil E. Nubatonis, Implementasi Prinsip-Prinsip Good Governance Dalam Meningkatkan Kinerja Organisasi Pelayanan Publik, JISIP: Jurnal Ilmu Sosial dan Ilmu Politik Unitri, Vol. 3, No. 1, 2014, Halaman 17.

[18] United Nastion Economic Communication for Europe, Guidebook on Promoting Good Governance in PublicPrivate Partnership, (New York and Ganeva :United Nation, 2008. Halaman 13-14.

[19] Y. Cahyo Kristiyono, Implementasi Alih Fungsi Penggunaan Tanah Dari Lahan Pertanian Menjadi Lahan Non Pertanian Di Kabupaten Klaten Berdasarkan UU No. 26 Tahun 2007 Tentang Penataan Ruang, Jurnal Repertorium Unsemar, Vol. IV No.1 Januari-Juni 2017.

[20] Zullaika Tipe Nurhidayah dkk., Aspek Keadilan Alih Fungsi Lahan Pertanian Ke Non Pertanian (Studi Kecamatan Nguter Kabupaten Sukoharjo), Jurnal Repertorium Unsemar, vol.VI No.2, Juli-Desember 2017

[21] Act Number 26 Year 2007 about Spatial Planning.

[22] Act Number 32 Year 2009 about Environmental Protec-tion and Management.

[23] Act Number 14 of 2008 about public information disclosure.

[24] Local Regulation of Surabaya City Number 12 Year 2014 about Surabaya Urban Spatial Plan Year 2014-2034.

[25] Wahyu Eka, Wahana Lingkungan Hidup Indonesia Daerah Jawa Timur (2018, Juni 01) Personal Interview 